2005. Available from: www.who.int/csr/disease/influenza/ WHO_CDS_2005_29/en/index.html.

5. Belshe R. The origins of pandemic influenza - lessons from the 1918 virus. N Engl J Med 2005; 353: 2209-11.

6. Kilbourne E. Influenza pandemics of the 20th century. Emerg Infect Dis 2006; 12(1): 9-14.

7. Taubenberger J, Reid A, Lourens R, Wang R, Jin G and Fanning T. Characterization of the 1918 influenza virus polymerases genes. Nature 2005; 437: 889-93.

8. Tumpey T, Basler C, Aguilar P et al. Characterisation of the reconstructed 1918 Spanish influenza pandemic virus. Science 2005; 310: 77-80.

9. Taubenberger J, Morens D. 1918 Influenza: the mother of all the pandemics. Emerg Infect Dis 2006; 12(1): 15-22.

10. Dowdle W. Influenza pandemic periodicity, virus recycling, and the art of risk assessment. Emerg Infect Dis 2006; 12(1): 34-9.

11. Department of Health and Ageing. Australian Management Plan for Pandemic Influenza. Canberra: Department of Health and Ageing, 2005. Available at: www.health.gov.au/ internet/wcms/Publishing.nsf/Content/phd-pandemic-plan. htm, accessed, 12 March 2006.

12. World Health Organization (WHO). Ten things you need to know about pandemic influenza. Weekly Epidemiological Record 2005; 80: 428-30.

13. World Health Organization (WHO). Influenza fact sheet 211. The World Health Organization, 2003. Available at: www. who.int/mediacentre/factsheets/fs211/en/, accessed 17 July.

14. Simonsen L, Clarke M, Schonberger L, Arden N, Cox N, Fukuda K. Pandemic versus epidemic influenza mortality: A pattern of changing age distribution. J Infect Dis 1998; 178: 53-60.
15. Paton R. Report on the influenza epidemics in New South Wales in 1919. Sydney: New South Wales Department of Health, 1919.

16. World Health Organization (WHO). Avian influenza and the significance of its transmission to humans - information from WHO. Technical Brief. J Environ Health 2005; 68(3): 41-2.

17. Fauci S. Pandemic influenza threat and preparedness. Emerg Infect Dis 2006; 12(1): 73-7.

18. Wong S, Yuen K. Avian influenza virus infections in humans. Chest 2006; 129(1): 156-68.

19. World Health Organization. Cumulative number of confirmed human cases of avian influenza A/(H5N1) reported to WHO, 28 September 2006. At www.who.int/csr/disease/avian_ influenza/country/cases_table_2006_09_28/en/index.html, accessed October 2006.

20. Centers for Disease Control and Prevention. Update: Influenza activity-United States and worldwide, 2003-04 season, and composition of the 2004-05 influenza vaccine. JAMA 2004; 292:1420-1423.

21. Writing committee of the World Health Organization (WHO). Current concepts: avian influenza A (H5N1) infection in humans. N Engl J Med 2005; 353(13): 1374-85.

22. World Health Organization Epidemic and pandemic alert and response. Avian influenza-situation in Indonesia-update 14. 23 May 2006. At www.who.int/csr/don/2006_05_23/en/index. html, accessed August 2006.

23. World Health Organization. Epidemiology of WHO-confirmed human cases of avian influenza A (H5N1) infection. Weekly Epidemiological Record 2006; 81: 249-60.

24. Taubenberger J, Morens D. Influenza revisited. Emerg Infect Dis 2006; 12(1): 1-2.

\title{
AN AUSTRALIAN PERSPECTIVE OF THE 1918-1919 INFLUENZA PANDEMIC
}

Peter Curson and Kevin McCracken

Department of Human Geography

Macquarie University

\section{ABSTRACT}

The 1918-1919 influenza pandemic stands as one of the greatest natural disasters of all time. In a little over a year the disease affected hundreds of millions of people and killed between 50 and 100 million. When the disease finally reached Australia in 1919 it caused more than 12,000 deaths. While the death rate was lower than in many other countries, the pandemic was a major demographic and social tragedy, affecting the lives of millions of Australians. This paper briefly assesses the impact of the pandemic on Australia and NSW with particular reference to the demographic and social impact and the measures advanced to contain it.

The 1918-1919 influenza pandemic remains among the greatest natural disasters of recorded history, rivalling the Black Death of the 14th century in mortality and social and economic effects. Emerging in Europe in the final months of the Great War, in the short space of a little over a year the pandemic swept around the world, killing between 50 and 100 million people. ${ }^{1}$ Few families or communities escaped its effects and possibly 25-30 per cent of the world's population was infected with influenza in 1918-1919. There was a series of pandemic waves, the first striking in the Northern Hemisphere spring of 1918. By October the disease had reached New Zealand. Despite a vigorous policy of maritime quarantine, the disease reached Australia in early 1919. The first wave in NSW occurred between mid March and late May, affecting twice as many males as females and resulting in about 31 per cent of total deaths. The second wave peaked in June and July and was more virulent than the first - it produced a higher mortality rate, involved more females and affected far more people over the age of 50 years (Figures 1 and 2). ${ }^{2}$

In Australia the pandemic was a major demographic and social tragedy, affecting the lives of millions of people. In a period of six months in 1919, probably more than 15,000 died from influenza and possibly as many as two million 
Australians were infected. The 1920 Official Year Book of the Commonwealth of Australia put forward a figure of just under 12,000 deaths ${ }^{3}$, but that is almost certainly an underestimate by at least 3000 to 4000 . More than 5000 marriages were affected by the loss of a partner and over 5000 children lost one or both parents. In 1919, almost 40 per cent of Sydney's population had influenza, more than
4000 people died, and in some parts of Sydney influenza deaths comprised up to 50 per cent of all deaths.

Unlike other influenza pandemics, which mainly impacted on people at the extremes of life, the 1918-1919 outbreak infected young, healthy adults. In NSW, more than 52 per cent of all deaths occurred in people aged between 20 and 39 years, and there were twice as many deaths from

\section{FIGURE 1}

NUMBER OF DEATHS PER WEEK DURING THE 1919 INFLUENZA PANDEMIC, NEW SOUTH WALES

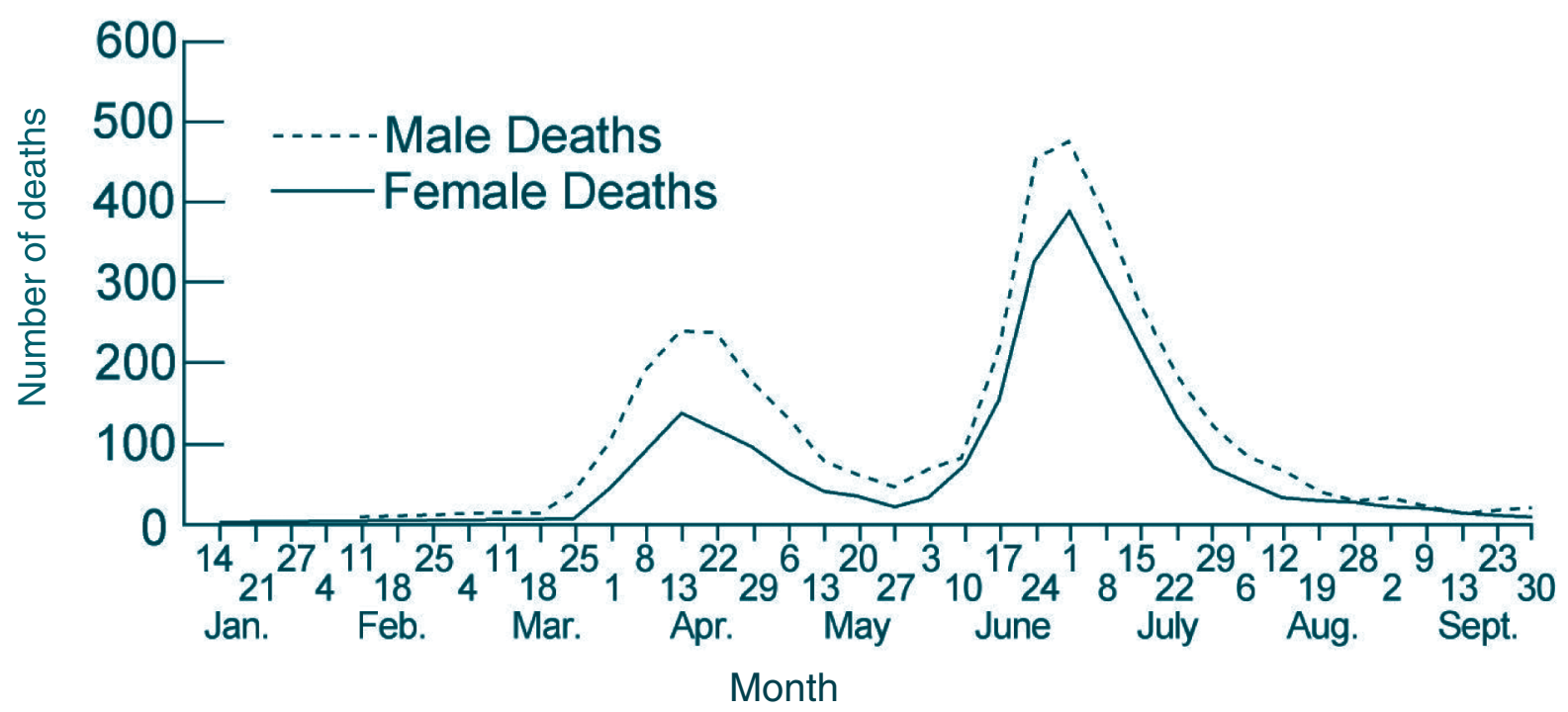

Source: NSW Department of Public Health-Influenza Report 1920

\section{FIGURE 2}

DEATH RATES FOR 5-YEAR AGE GROUPS FOR THE TWO WAVES OF THE 1919 INFLUENZA PANDEMIC, NEW SOUTH WALES

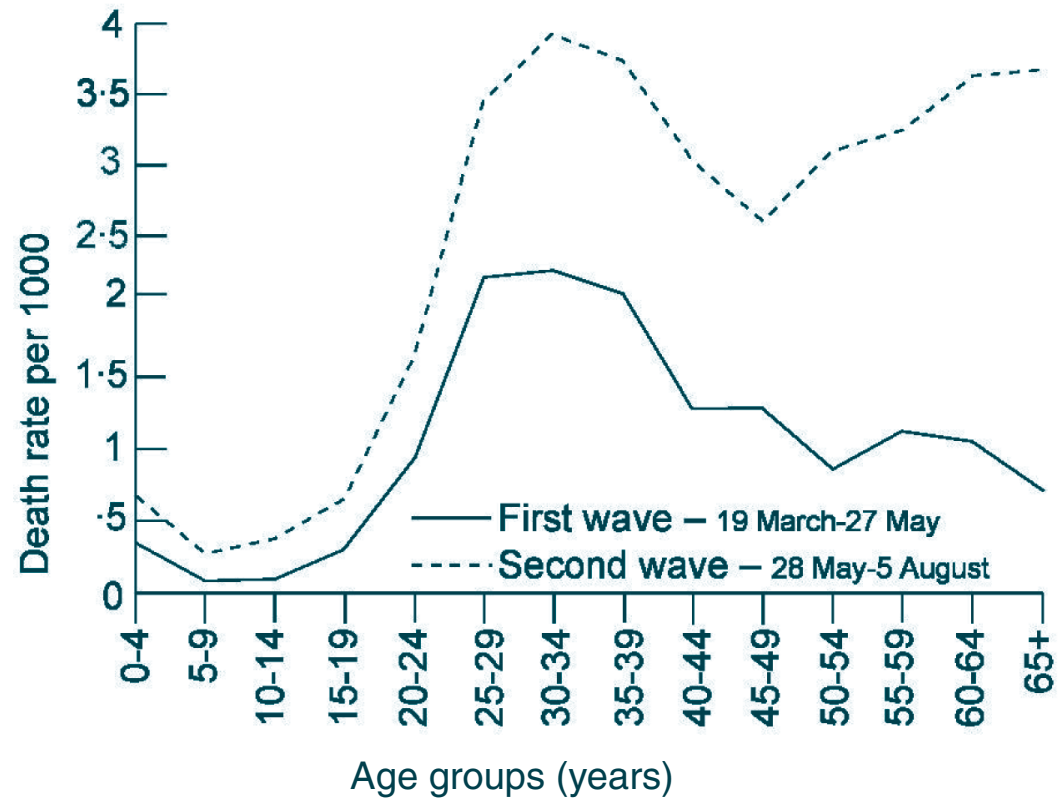

Source: NSW Department of Public Health—Influenza Report 1920 
influenza in this age cohort than in the $0-4$ years and the 50 years and over age groups combined. Adults aged between 25 and 34 years contributed almost one third of all deaths. Such an age distribution stands in sharp contrast to most other influenza pandemics, including the 1891 influenza pandemic, when the majority of deaths in NSW occurred in people aged over 60 (Figures 3 and 4). ${ }^{4}$ It is uncertain why the epidemic infected so many people in the prime of life.

As indicated in Figures 3 and 4, the epidemic also took a substantially heavier toll of males than females. It is hypothesised that this sex-patterning is explained by differential socio-behavioural risk factors relating to geographic mobility and mixing; for example, the higher workforce participation rate of males and male-dominated practices such as drinking in hotel bars and attending crowded sporting events were likely sources of increased risk of infection.

Globally, the mortality rate varied considerably. Australia experienced a mortality rate of close to three deaths per thousand, while in nearby New Zealand it was almost double this figure. In some isolated populations the pandemic took a much heavier toll. In Western Samoa there were 8,500 deaths in a total population of only 38,000 - a death rate of 221.92 per thousand. ${ }^{5}$

Indigenous populations were also severely affected. In New Zealand, the Maori population was seven times more likely to die from influenza than European New Zealanders, and their death rate exceeded 42.3 per thousand. ${ }^{6}$ Australia's indigenous population was also severely affected, with a mortality rate approaching 50 per cent in some communities. ${ }^{7}$ The pandemic created terror among the inhabitants of Aboriginal stations and missions. At Barambah Station in Queensland at least 600 contracted the disease and in early 1919 a total of 800 became infected at Yarabah and Taroom Stations.

Australia, like most countries, was ill prepared to cope with such a disaster. The war had severely disrupted social and economic life, removed many medical personnel and disrupted public services. In an attempt to contain the outbreak, Australian authorities instigated a combination of strategies. Schools, theatres, dance halls, churches, pubs and other places of public congregation were shut, streets were sprayed, special isolation depots were established and people were compelled to wear masks in public. Movement by public transport was restricted and state borders were closed, with quarantine camps established at border crossings. Attempts were made to produce a vaccine using a mixture of victims' sputum, streptococcus and staphylococcus concoctions. Hundreds of thousands of people demanded inoculation and the government established more than 1260 public inoculation depots throughout Sydney, as well as relying on private practitioners. In a little over six months, more than 819,000 inoculations were performed, including more than 440,000 in Sydney, which was more than 50 per cent of the city's population. ${ }^{9}$ People were urged to practice personal preventive measures such as cough etiquette, hand washing, ventilation and disinfection.

\section{FIGURE 3}

\section{COMPARISON OF DEATH RATES FOR MALES, IN 5-YEAR AGE GROUPS, FOR THE 1891 AND 1919 INFLUENZA}

PANDEMICS, NEW SOUTH WALES
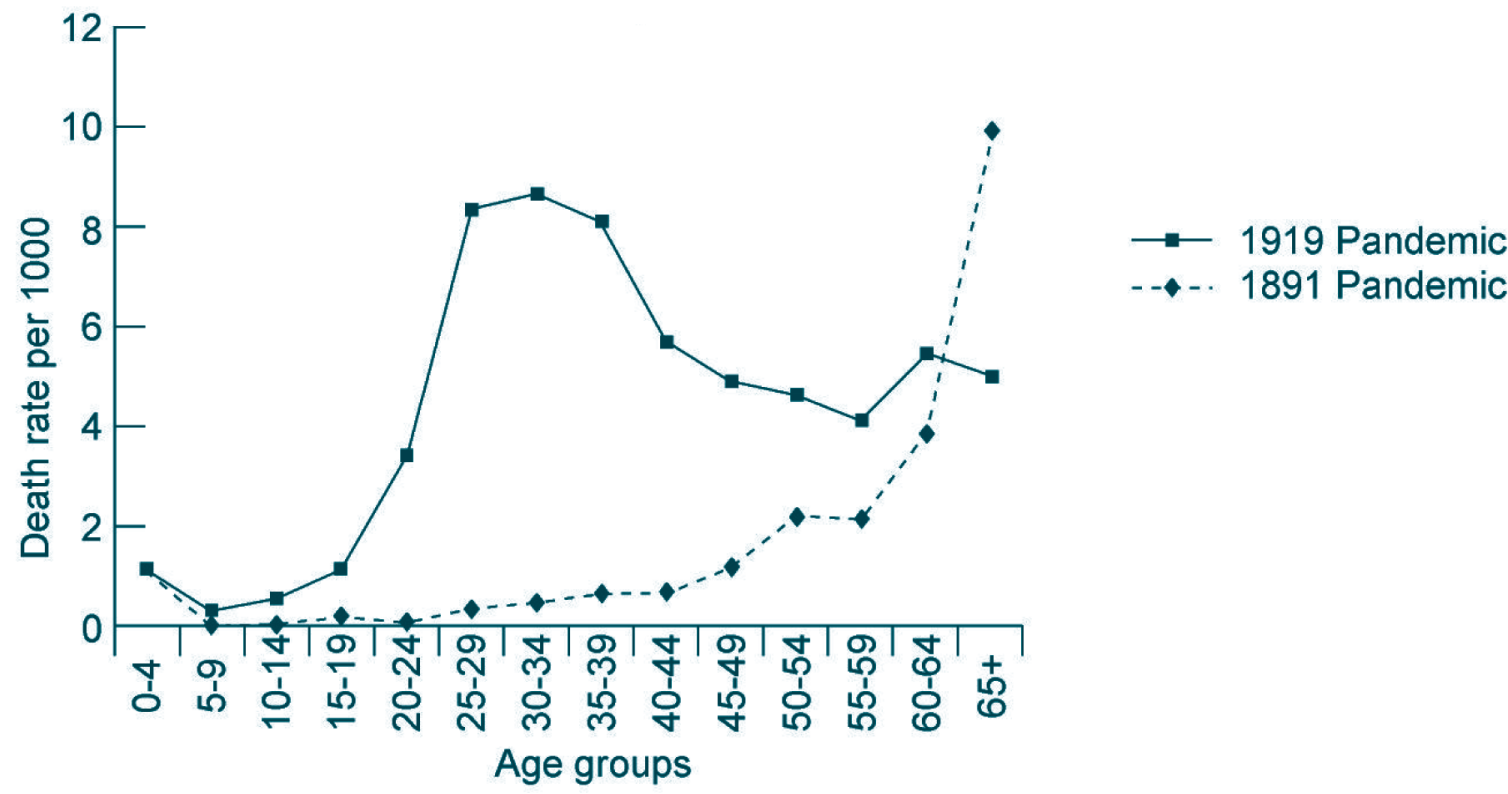

Source: NSW Department of Public Health—Influenza Report 1920 
FIGURE 4

\section{COMPARISON OF DEATH RATES FOR FEMALES, IN 5-YEAR AGE GROUPS, FOR THE 1891 AND 1919 INFLUENZA PANDEMICS, NEW SOUTH WALES}

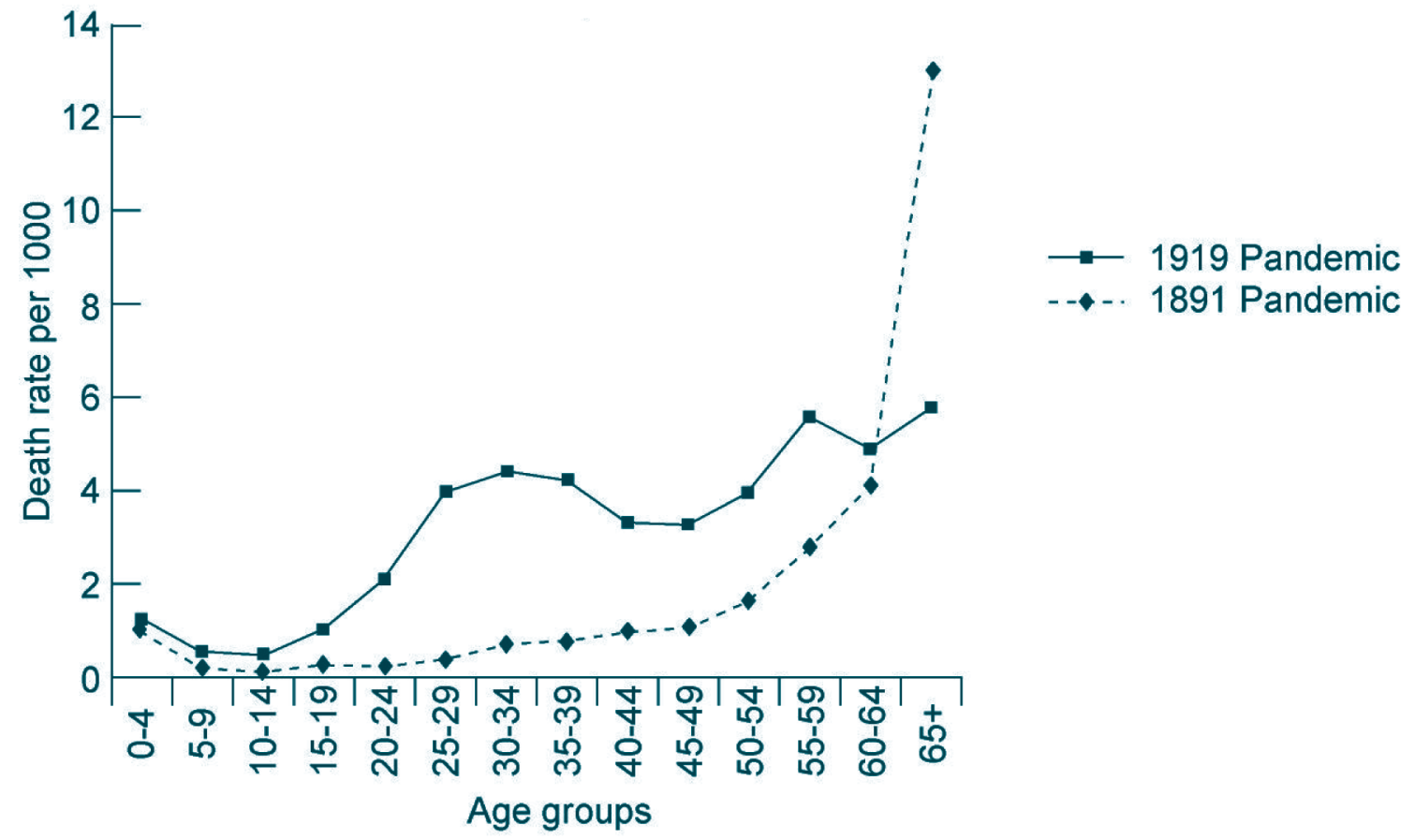

Source: NSW Department of Public Health—Influenza Report 1920

In a short time, hospitals were overwhelmed and health care workers pushed to breaking point. At the onset of the pandemic, NSW had only 2000 hospital beds. Between January and September more than 25,000 people in NSW were admitted to hospital with influenza, requiring the establishment of hundreds of temporary influenza hospitals in private homes, schools, showground buildings, churches, gaols, bowling clubs, tearooms, drill halls and courthouses. The pandemic also took its toll on medical and healthcare workers. In Sydney more than 800 were incapacitated with influenza and many temporary hospitals had to be staffed by lay volunteers.

The public was stunned by the ferocity of the pandemic and newspapers fanned public unease with regular reports of cases and deaths and lurid descriptions of former plagues. There were reports of people waking fine in the morning and being dead from influenza by nightfall. With so many people off work due to illness, normal services and activities were severely disrupted. Thousands sought popular cures and medicines. Many people rebelled by circumventing the quarantine blockade at state borders or refusing to wear masks. Waterside workers refused to unload ships for fear of infection and some public workers demanded 'epidemic pay'. People shunned outsiders and interstate visitors, fearing they were a potential source of infection.

The pandemic caused disputes between all the states and between the states and the Commonwealth over border closures, differing policies of border controls and quarantine, interstate transport links, and the quarantine of returning servicemen. Eventually, cooperation between the states and the Commonwealth authorities was abandoned, with each state imposing its own conditions and organising its own containment policies.

There are many lessons to be learnt from Australia's experience of influenza in 1919. The pandemic tells us something about how people and communities react to severe disease crises, particularly in a context where governments and conventional medical science offer no real measures of abatement or cure. Secondly, Australia's experience with the pandemic demonstrates how public health preparedness for such events requires a full appreciation of the impact on health care facilities and medical personnel, as well as of the logistical difficulties of delivering vaccines or other drugs in a timely fashion to a large population. Thirdly, it is clear that the media play a defining role in presenting a pandemic to the public and can, by word and image, temper or enflame human reaction. Many of the measures introduced by governments to contain pandemics, such as quarantine, border controls and restrictions on travel and public gatherings, may in their own right aggravate the human response by heightening fears and anxieties. Finally, the 1919 experience clearly demonstrates that cooperation between various governments and government authorities during such crises cannot always be taken for granted. 


\section{REFERENCES}

1. Johnson NPAS, Mueller J. Updating the accounts: Global mortality of the 1918-1920 'Spanish' influenza pandemic. Bull Hist Med 2002; 76(1): 105-15.

2. Mc Cracken K, Curson P. Flu Downunder: A demographic and geographic analysis of the 1919 epidemic in Sydney, Australia. In Phillips H, Killingray D, editors. The Spanish influenza pandemic of 1918-19: New perspectives. London, Routledge; 2003: 121-2.

3. Commonwealth Statistician. Official Year Book of the Commonwealth of Australia, No. 13 - 1920. Melbourne. Commonwealth Bureau of Census and Statistics. 1920: 190, 1128.

4. NSW Department of Public Health. Report of the DirectorGeneral of Public Health to the Hon. The Minister of Health on the influenza epidemic in NSW in 1919. Joint volume of papers presented to the NSW Legislative Council and Legislative Assembly, First Session 1920. Sydney, Government Printer: 177.
5. Rice GW. Black November: The 1918 influenza pandemic in New Zealand. Christchurch, University of Canterbury Press; 2005: 201.

6. Rice GW. Black November: The 1918 influenza pandemic in New Zealand. Christchurch, University of Canterbury Press; 2005: 159.

7. Cleland Burton J. Disease among the Australian Aborigines. J Trop Med Hyg 1928; 6(XXX1): 65.

8. Basedow H. Diseases of the Australian Aborigines. J Trop Med Hyg 1932; 12(XXXV): 184-5.

9. NSW Department of Public Health. Report of the DirectorGeneral of Public Health to the Hon. The Minister of Health on the influenza epidemic in NSW in 1919. Joint volume of papers presented to the NSW Legislative Council and Legislative Assembly, First Session 1920. Sydney, Government Printer: 153-5. 용

\section{THE RISK OF AVIAN INFLUENZA IN BIRDS IN AUSTRALIA}

\section{George Arzey}

Elizabeth Macarthur Agricultural Institute

NSW Department of Primary Industries

\section{ABSTRACT}

Avian influenza viruses may cause mild or severe disease in birds. There have been five recorded outbreaks of highly pathogenic avian influenza in birds in Australia, all of which were caused by the $\mathrm{H} 7$ subtype. These were quickly controlled and similar coordinated responses are expected for possible future outbreaks of avian influenza. Migratory birds are not regarded as the source of these outbreaks, and the prevalence of avian influenza viruses in wild birds in Australia is very low. Avian influenza H5N1, which emerged in birds in China in 1996, has spread to bird flocks in Asia, Europe and Africa. The main carriers of avian influenza, ducks, do not migrate to Australia, and currently the risk of $\mathrm{H} 5 \mathrm{~N} 1$ occurring in Australian birds appears to be low. Nevertheless, surveillance and response plans for outbreaks of highly pathogenic avian influenza have recently been upgraded across Australia.

Avian influenza is a viral disease that primarily infects birds. This article describes avian influenza and provides information about outbreaks of avian influenza that have occurred in bird flocks in Australia. It also examines the risk of avian influenza $\mathrm{H} 5 \mathrm{~N} 1$ (hereafter also referred to as H5N1) occurring in birds in Australia.

Avian influenza viruses are classified into two groups based on their ability to cause disease in birds: the highly pathogenic strains that multiply in a wide variety of organs in the bird and can cause severe disease; and the low pathogenic strains that multiply in the intestines and respiratory tract only, and cause either no or mild disease, and low mortality. ${ }^{1}$ Avian influenza viruses are also classified by the combination of two groups of proteins: hemagglutinin proteins $(\mathrm{H})$ and neuraminidase proteins $(\mathrm{N})$.

Influenza viruses have been reported in more than 90 species of birds. Ducks and other waterfowl (see Box 1 for definitions of the types of birds referred to in this article) are the recognised reservoir of avian influenza viruses and harbour all known subtypes of the influenza A virus. The low pathogenic viruses, including some $\mathrm{H} 7$ and $\mathrm{H} 5$ subtypes (which are the subtypes that most often turn into the highly pathogenic strains), rarely cause clinical signs in waterfowl, unlike the highly pathogenic $\mathrm{H} 5 \mathrm{~N} 1$, which can cause disease in these birds. Other wild waterbirds, like shorebirds, carry the low pathogenic avian influenza viruses, but at a much lower frequency than waterfowl. ${ }^{1}$

The introduction of low pathogenic viruses into susceptible poultry populations occasionally results in a mutational shift in the virus to produce highly pathogenic strains associated with severe disease. ${ }^{2}$ Clinical signs of infected poultry include: reluctance to move, eat or drink; droopy appearance; severe respiratory distress; inability to walk or stand; unusual head and neck posture; and escalating flock mortality. Poultry can become infected with avian influenza through direct contact with an infected bird or infected material such as faeces, or through the consumption of food or water that is contaminated with the virus (which has the ability to survive several days in medium temperatures in areas not exposed to direct sunlight). ${ }^{3}$

Large scale outbreaks of highly pathogenic $\mathrm{H} 5$ and $\mathrm{H} 7$ avian influenza lasting for many years have occurred in poultry on many occasions in different regions of the world. ${ }^{4}$ However, 